\title{
Phosphoric Acid Adsorbed on Silica-Ceria Matrix Obtained by Sol-Gel Method: Studies of Local Structure, Texture and Acid Property
}

\author{
Fábio L. Pissetti, ${ }^{a}$ Maria Suzana P. Francisco, ${ }^{a}$ Richard Landers ${ }^{b}$ and Yoshitaka Gushikem ${ }^{*, a}$ \\ ${ }^{a}$ Instituto de Química, Universidade Estadual de Campinas, CP 6154, 13084-971 Campinas-SP, Brazil \\ ${ }^{b}$ Instituto de Física Gleb Wataghin, Universidade Estadual de Campinas, CP 6165 , \\ 13084-971 Campinas-SP, Brazil
}

\begin{abstract}
Óxidos mistos de $\mathrm{SiO}_{2} / \mathrm{CeO}_{2}$ (designados como $\mathrm{SC}$ ) contendo quantidades variáveis de céria, $\mathrm{SC} 1=5,6, \mathrm{SC} 2=8,0$ e SC3 $=13,0$ (\% em massa), foram preparados pelo método de processamento sol-gel e obtidos como sólidos amorfos possuindo áreas superficiais específicas de $\mathrm{SC} 1=463, \mathrm{SC} 2=474$ e SC3 $=460 \mathrm{~m}^{2} \mathrm{~g}^{-1}$. Íons fosfatos foram imobilizados na superfície destes sólidos, através da ligação química Ce-O-P, pela imersão de SC em uma solução de ácido fosfórico. Este procedimento produziu sólidos com as seguintes quantidades de $\mathrm{P}$ adsorvidas na superfície (em \% atômica): SCP1 $=0,60, \mathrm{SCP} 2=0,71$ e SCP3 = 1,63. A energia de ligação P $2 \mathrm{p}_{3 / 2}$, obtida por XPS, e o único pico observado em -10 ppm, por NMR de ${ }^{31} \mathrm{P}$, revelaram que o fosfato adsorvido na superfície é a espécie $\mathrm{H}_{2} \mathrm{PO}_{4}^{-}$. Utilizando-se piridina como sonda molecular, somente sítios ácidos de Brønsted foram detectados. A determinação das quantidades destes sítios ácidos, feita pela adsorção de $\mathrm{NH}_{3}$ gasosa sobre a superfície, revelou os seguintes valores para cada sólido tratado com o íon fosfato: $\mathrm{SCP} 1=0,37, \mathrm{SCP} 2=0,43$ e SCP3 $=0,51$ mmol g-1.
\end{abstract}

$\mathrm{SiO}_{2} / \mathrm{CeO}_{2}$ mixed oxide (designated as $\mathrm{SC}$ ) with variable ceria contents, $\mathrm{SC} 1=5.6$, $\mathrm{SC} 2=8.0$ and $\mathrm{SC} 3=13.0 \mathrm{wt} \%$, prepared by the sol-gel processing method, were obtained as amorphous solids possessing specific surface areas of SC1 $=463, \mathrm{SC} 2=474$ and SC3 $=$ $460 \mathrm{~m}^{2} \mathrm{~g}^{-1}$. Phosphate ions were immobilized onto the surface of these solids through Ce-O$\mathrm{P}$ bonding by immersing SC into a phosphoric acid solution. Solids with the following $\mathrm{P}$ contents were obtained (in atom $\%$ ): $\mathrm{SCP} 1=0.60, \mathrm{SCP} 2=0.71$ and $\mathrm{SCP} 3=1.63$. The binding energy peak $\mathrm{P} 2 \mathrm{p}_{3 / 2}$ at $c a$. $134.0 \mathrm{eV}$, observed by XPS, and the ${ }^{31} \mathrm{P}$ MAS NMR single peak, observed at $c a$. -10 ppm, revealed that $\mathrm{H}_{2} \mathrm{PO}_{4}^{-}$is the species present on the surface of the matrices. Using pyridine as a molecular probe, only Brønsted acid sites could be detected. The amount of these acid sites, determined by ammonia gas adsorption on the surface, reached the following values for each phosphate-treated solid: SCP1 $=0.37$, $\mathrm{SCP} 2=0.43$ and SCP3 $=0.51 \mathrm{mmol} \mathrm{g}^{-1}$.

Keywords: silica-ceria, silica-ceria-phosphate, sol-gel method, acid sites

\section{Introduction}

Cerium(IV) phosphate can be prepared by reacting phosphoric acid with diammonium cerium(IV) nitrate, by an acid sol-gel process involving controlled precipitation, ${ }^{1}$ or by using a chelating agent to obtain nanocrystalline mesoporous solids with controlled pore size. ${ }^{2}$ It can also be obtained by hydrothermal synthesis from the reaction of $\mathrm{CeO}_{2}$ and phosphoric acid. ${ }^{3} \mathrm{~A}$ recent interesting process described in the literature consists of a reproducible and

*e-mail: gushikem@iqm.unicamp.br controllable route to produce cerium phosphate nanotubes. ${ }^{4}$

Cerium phosphate can have many applications as ceramic material, ${ }^{5}$ as a glass presenting optical ${ }^{6}$ and luminescent ${ }^{7}$ properties, as ion exchanger ${ }^{8}$ and catalyst. ${ }^{9}$ It can also be prepared as phosphate particles dispersed in hybrid organic-inorganic matrices, aiming at their use in filtering process. ${ }^{10,11}$

Processes to prepare metal oxides incorporated into a silica matrix have been described in recent years. Mixed oxides of the $\mathrm{SiO}_{2} / \mathrm{M}_{\mathrm{x}} \mathrm{O}_{\mathrm{y}}$ type have been obtained by the sol-gel processing method, where the metal oxides are incorporated into the silica matrices as very fine and 
homogeneously dispersed particles. ${ }^{12-15} \mathrm{SiO}_{2} / \mathrm{M}_{\mathrm{x}} \mathrm{O}_{\mathrm{y}}$ obtained by this method normally presents high thermal and mechanical stability provided by the silica framework. ${ }^{13,16}$ Despite this rigid structure, the metal oxide $\mathrm{M}_{\mathrm{x}} \mathrm{O}_{\mathrm{y}}$ presents reactive $\mathrm{MOH}$ groups on the surface which can easily react with organic or inorganic acids forming a stable linkage. ${ }^{17}$

In this work, the preparation of microporous $\mathrm{SiO}_{2} / \mathrm{CeO}_{2}$ mixed oxide by the sol-gel process and the subsequent immobilization of phosphate groups onto the surface of this matrix are reported. The objective was to obtain cerium(IV) confined in a silica matrix and attached to phosphate species by Ce-O-P bonds. The textural, thermal stability, local structure and acidic properties of $\mathrm{SiO}_{2} /$ $\mathrm{CeO}_{2} /$ Phosphate were investigated by XRD, XPS, FTIR and SEM/EDS techniques.

\section{Experimental}

\section{Preparation of $\mathrm{SiO}_{2} / \mathrm{CeO}_{2}$ by the sol-gel method}

The silica/ceria mixed oxide, $\mathrm{SiO}_{2} / \mathrm{CeO}_{2}$, was prepared by the sol-gel method. In a reaction flask containing 150 $\mathrm{mL}$ of absolute ethanol (Synth), $175 \mathrm{~mL}$ of tetraethylorthosilicate (TEOS-Aldrich), $16 \mathrm{~mL}$ of twice distilled $\mathrm{H}_{2} \mathrm{O}$ and $2.3 \mathrm{~mL}$ of concentrated nitric acid were added and the resulting solution was heated with constant stirring at $353 \mathrm{~K}$ for 3 hours. After cooling the solution, different amounts of $\left(\mathrm{NH}_{4}\right)_{2} \mathrm{Ce}\left(\mathrm{NO}_{3}\right)_{6}(0.014,0.027$ and $0.040 \mathrm{~mol})$, dissolved in mixtures containing $100 \mathrm{~mL}$ of ethanol and $25 \mathrm{~mL}$ of twice distilled water, were added. The mixtures were stirred for additional 3 hours at $298 \mathrm{~K}$. Then, $1.3 \mathrm{~mL}$ of concentrated $\mathrm{HNO}_{3}$ in $9.5 \mathrm{~mL}$ of distilled water were added and the solution was stirred for other 2 hours. The solvent was evaporated from the mixtures at $373 \mathrm{~K}$, producing gelatinous materials. The gels obtained were heated at $473 \mathrm{~K}$ under constant air flow for two hours. The materials obtained with increasing amount of ceria will be hereafter designated as SC1, SC2 and SC3.

The thermal stabilities were investigated submitting SC1, SC2 and SC3 to heat treatment at 473, 673, 873, 1073 and $1273 \mathrm{~K}$, with a plateau of $8 \mathrm{~h}$ for each temperature.

\section{Phosphate adsorption on the $\mathrm{SiO}_{2} / \mathrm{CeO}_{2}$ mixed oxide}

About $1.5 \mathrm{~g}$ of each $\mathrm{SC}$ were immersed in $40 \mathrm{~mL}$ of a $0.1 \mathrm{~mol} \mathrm{~L}^{-1} \mathrm{H}_{3} \mathrm{PO}_{4}$ solution and allowed to stand, with occasional shaking, for 72 hours. The mixtures were filtered, washed with water and dried at room temperature. They were designated as SCP1, SCP2 and SCP3, respectively.

\section{$X$-ray diffraction and $X$-ray fluorescence}

X-ray diffraction patterns were obtained on a Shimadzu XRD-6000 diffractometer by using $\mathrm{Cu} \mathrm{K}_{\alpha}$ radiation $(\lambda=0.154 \mathrm{~nm}, 40 \mathrm{kV}$ per $30 \mathrm{~mA})$ and a sweeping velocity of 2 degree min $^{-1}$ (units of $2 \theta$ ).

The amount of cerium in the silica matrix was determined by X-ray fluorescence analysis. Mechanical mixtures of finely powdered $\mathrm{SiO}_{2}$ (Merck) and $\mathrm{CeO}_{2}$ (Carlo Erba), containing different ratios of $\mathrm{Si} / \mathrm{Ce}$, were used to obtain the calibration curve. The measurements were carried out on a SHIMADZU EDX-700 using a rhodium $\mathrm{X}$-ray anode $(50 \mathrm{kV})$ as source.

\section{Specific surface area $\left(S_{B E T}\right)$ and average pore size}

Samples of the SC and SCP materials were previously heated at $343 \mathrm{~K}$ under vacuum $\left(1.3 \times 10^{-3}\right.$ $\mathrm{Pa})$ for $1 \mathrm{~h}$. The specific surface areas were determined by the BET method, while the average pore size was determined by nitrogen adsorption-desorption isotherms (using the BJH method) on an ASAP 2010 apparatus from Micromeritics.

\section{Scanning electron microscopy (SEM) and X-ray emission} analyses (EDS)

Samples were fixed onto a double faced tape adhered to an aluminum support and coated with a layer of gold (ca. $15 \mathrm{~nm}$ ) by a BalTec SCD 050 Sputter Coater apparatus (60 mA current for $60 \mathrm{~s}$ ). The scanning electron microscopy analysis (SEM) was carried out using low vacuum microscopy on a JSM 5900LV equipment operating at an accelerating voltage of $25 \mathrm{kV}$. Images were obtained by using secondary electrons. X-ray emission spectroscopy (EDS) was used for elemental mapping with a Noram Voyager instrument. The micrographs and the elemental maps were obtained for all contents of $\mathrm{CeO}_{2}$ oxide supported by silica.

High power decoupling-magic angle spinning ${ }^{31} \mathrm{P} N M R$

The high power decoupling magic angle spinning (HPDEC-MAS) ${ }^{31} \mathrm{P}$ NMR spectra of all solids were obtained at room temperature on a Bruker AC300/P spectrometer operating at $121 \mathrm{MHz}$. Conditions used were a sequential pulse with an acquisition time of $41 \mathrm{~ms}$ and a relaxation time of 4 seconds. Phosphoric acid (85 wt\%; $\delta=0 \mathrm{ppm})$ and sodium hydrogen phosphate $(\delta=0.9 \mathrm{ppm})$ were used as primary and secondary references for the chemical shifts, with a spectral width of $50 \times 10^{3} \mathrm{~Hz}$. 


\section{X-ray Photoelectron Spectroscopy (XPS)}

Spectra were recorded on a VSW HA-100 Spherical Analyzer operating with pass energy of $44 \mathrm{eV}$ and an $\mathrm{Al}-$ $\mathrm{K}_{\alpha}$ radiation source $(1486.6 \mathrm{eV})$. Samples were prepared as powder pressed into pellets, fixed to a stainless steel sample holder with double-faced tape and analyzed as prepared. The binding energies were referenced to the $\mathrm{C}$ 1s line at $284.6 \mathrm{eV}$ and the photoemission lines were simulated with Gaussian line shapes. The relative surface compositions were calculated from the photoelectron peak areas after correction for the photo-ionization cross section and the difference in the electron escape depth. ${ }^{18}$ The atomic compositions were estimated from the $\mathrm{C} 1 \mathrm{~s}, \mathrm{O} 1 \mathrm{~s}$, $\mathrm{Si} 2 \mathrm{p}, \mathrm{P} 2 \mathrm{p}$ and $\mathrm{Ce} 3 \mathrm{~d}_{5 / 2}$ integrated peak areas.

\section{Infrared spectrometry for determining acidic properties}

The Brønsted acid sites on the surface of all SC and SCP samples were studied by analyzing the infrared spectra of pyridine as a probe molecule. About $100 \mathrm{mg}$ of the ground sample were wetted with liquid pyridine at room temperature and the samples were then submitted to vacuum $\left(1.3 \times 10^{-5}\right.$ $\mathrm{Pa}$ ), initially at room temperature, to eliminate physically adsorbed pyridine. The self-supported pressed disks were heated under vacuum at 373 and $473 \mathrm{~K}$ and, for each temperature, spectra were obtained at room temperature on a Bomen Hartmann \& Braun (MB-Series) spectrophotometer. FTIR spectra of samples as prepared and of the heated materials were obtained on the same spectrophotometer, using pressed $\mathrm{KBr}$ pellets containing $1 \mathrm{wt} \%$ of the material.

\section{Ammonia gas adsorption}

A $250 \mathrm{~mL}$ erlenmeyer flask with about $1 \mathrm{~g}$ of each SCP material was filled with $\mathrm{NH}_{3}$ gas and closed for 30 minutes at room temperature. The excess of gas was pumped off at $1.3 \times 10^{-3} \mathrm{~Pa}$ at room temperature. The amount of ammonia adsorbed in the material was determined by the Kjeldhal method.

\section{Results and Discussion}

\section{Characteristics of the samples}

The X-ray fluorescence analyses of the samples showed the following amounts of $\mathrm{CeO}_{2}$ for the three SC mixed oxides (in wt $\%$ ): 5.6, 8.9 and 13.0, which correspond to $0.33,0.53$ and $0.76 \mathrm{mmol}$ of Ce per gram, respectively. The specific surface areas, $\mathrm{S}_{\mathrm{BET}}$, and the average pore diameters, $\overline{\mathbf{r}}$, are presented in Table 1 .
Table 1. Values of specific surface area, $\mathrm{S}_{\mathrm{BET}}$, and average pore diameters, $\overline{\mathbf{r}}$

\begin{tabular}{lccc}
\hline Material & Designated as & $\mathrm{S}_{\mathrm{BET}} /\left(\mathrm{m}^{2} \mathrm{~g}^{-1}\right)$ & $\overline{\mathbf{r}} / \mathrm{nm}$ \\
\hline $\mathrm{SiO}_{2} / 5.6 \% \mathrm{CeO}_{2}$ & $\mathrm{SC} 1$ & 463 & 1.7 \\
$\mathrm{SiO}_{2} / 8.9 \% \mathrm{CeO}_{2}$ & $\mathrm{SC} 2$ & 474 & 1.7 \\
$\mathrm{SiO}_{2} / 13 \% \mathrm{CeO}_{2}$ & $\mathrm{SC} 3$ & 460 & 1.7 \\
$\mathrm{SiO}_{2} / 5.6 \% \mathrm{CeO}_{2} / \mathrm{P}^{*}$ & $\mathrm{SCP} 1$ & 473 & 1.9 \\
$\mathrm{SiO}_{2} / 8.9 \% \mathrm{CeO}_{2} / \mathrm{P}^{*}$ & $\mathrm{SCP} 2$ & 477 & 1.7 \\
$\mathrm{SiO}_{2} / 13 \% \mathrm{CeO}_{2} / \mathrm{P}^{*}$ & $\mathrm{SCP} 3$ & 539 & 1.7 \\
\hline
\end{tabular}

*P $=$ phosphate.

The specific surface areas of SC1, SC2 and SC3 remained practically constant when compared with the corresponding modified solids SCP1, SCP2 and SCP3, except for SCP3, where a slight increase was observed. These results indicate that reaction of phosphoric acid with $\mathrm{CeO}_{2}$, resulting in formation of phosphate species on the surface, is not blocking the finest pores. Otherwise, a decrease of the specific surface areas by the species formed should be observed. ${ }^{19}$

Contents of P, Ce, Si and O on the surface of the SCP solids were determined by the XPS technique. Table 2 lists the results obtained.

Table 2. Elemental contents on SCP surface (in atom \%), determined by XPS

\begin{tabular}{lccc}
\hline Elements & SCP1/atom \% & SCP2/atom \% & SCP3/atom \% \\
\hline $\mathrm{P}$ & 0.60 & 0.71 & 1.63 \\
$\mathrm{Ce}$ & 0.22 & 0.31 & 0.60 \\
$\mathrm{Si}$ & 36.8 & 39.7 & 36.4 \\
$\mathrm{O}$ & 48.2 & 50.3 & 51.4 \\
\hline
\end{tabular}

As the amount of surface Ce increases on the surface, the quantity of $\mathrm{P}$ also increases, evidencing that phosphoric acid is retained by the reaction with the metal oxide sites on the surface.

Figure 1 shows the IR spectra of $\mathrm{SC}$ and pure $\mathrm{SiO}$ treated at $473 \mathrm{~K}$ and compared with SC3 calcined at 1273 $\mathrm{K}$. For pure $\mathrm{SiO}_{2}$, the band observed at $975 \mathrm{~cm}^{-1}$ (Figure 1d) is assigned to the $\mathrm{Si}-\mathrm{O}$ stretching mode $(\mathrm{vSiO})$ of free silanol, $\equiv \mathrm{Si}-\mathrm{OH}$, group. ${ }^{20}$ In the mixed oxide this frequency is shifted to $948 \mathrm{~cm}^{-1}$ (Figures 1a-c), due to the Si-O-Ce linkage formation..$^{21,22}$ This band disappears on heating SC3 (taken as a model material) at $1273 \mathrm{~K}$, presumably due to the breaking of the $\mathrm{Si}-\mathrm{O}-\mathrm{Ce}$ bonding as a consequence of the increase in $\mathrm{SiO}_{2}$ and $\mathrm{CeO}_{2}$ particles size.

\section{$X$-ray Diffraction patterns}

Figure 2 shows the XRD patterns for SC1, SC2 and SC3 samples submitted to thermal treatments at 473, 673, 


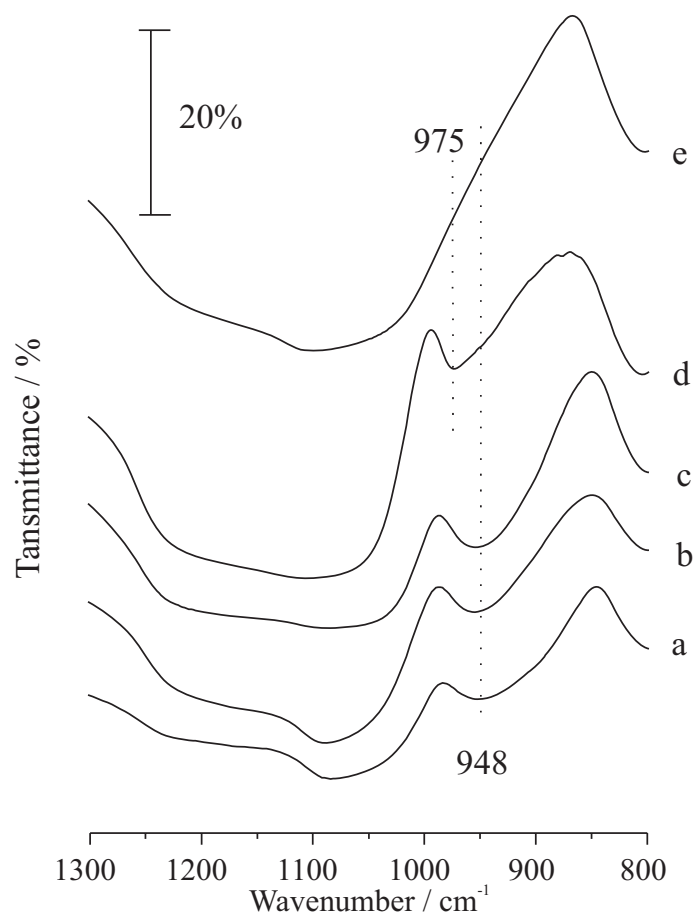

Figure 1. FTIR spectra of (a) $\mathrm{SC}$, b) $\mathrm{SC}$, (c) $\mathrm{SC} 3$, (d) $\mathrm{SiO}_{2}$ thermally treated at $473 \mathrm{~K}$ and (e) SC3 calcined at $1273 \mathrm{~K}$.

873, 1073 and $1273 \mathrm{~K}$. Comparing the corresponding diffraction peaks, particles of $\mathrm{CeO}_{2}$ incorporated into the mixed oxide present some degree of crystallinity, which increases as the temperature is raised from 473 up to 1273 K. For SC2 and SC3, which contain more ceria, at 1273 $\mathrm{K}$ (Figures $2 \mathrm{c}$ and $3 \mathrm{c}$ ) peaks at 28.5, 47.0 and 56.0 (in 2q) match with $\mathrm{CeO}_{2}$ cerianite structure (JCPDS, file number 34-0394). $\mathrm{SiO}_{2}$ particles remain amorphous at this temperature.

Scanning Electron Microscopy (SEM) and X-ray emission analysis (EDS)

Figure 3 shows the SEM micrographs and the corresponding cerium analyses by EDS (white points) for SCP3 (taken as the representative sample) thermally treated at 473 and $1273 \mathrm{~K}$. The elemental mappings as a function of the thermal treatment temperature reveal that the cerium oxide is, within the magnification used, well dispersed in the silica matrix. Such a degree of dispersion is important, since it enables a uniform distribution of phosphate species on the surface in the adsorption process. ${ }^{17,23}$

\section{${ }^{31} P$ NMR analysis}

${ }^{31} \mathrm{P}$ MAS NMR spectroscopy is a powerful technique for studying the environment of metal phosphates, since
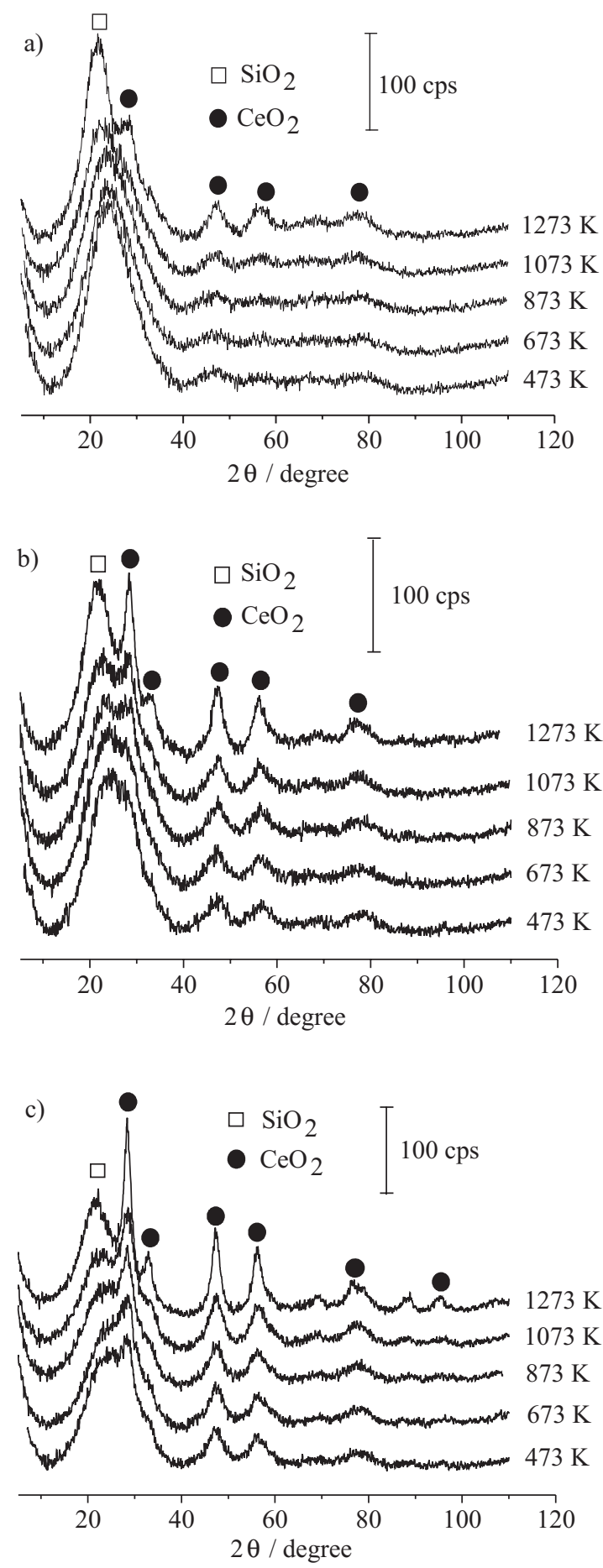

Figure 2. X-ray diffractograms of a) SC1, b) SC2 e c) SC3 samples, calcined at $473,673,873,1073$ and $1273 \mathrm{~K}$.

the chemical shift of the phosphate group is very sensitive to its local environment. In the present case, the spectra recorded for SCP1, SCP2 and SCP3 showed a single peak at $c a$. $-10 \mathrm{ppm}$ (Figure 4). In comparison with crystalline pure cerium phosphate, the observed chemical shift can be assigned to the dihydrogen phosphate species bonded to the ceria particle, Ce-O-P $(\mathrm{O})(\mathrm{OH})_{2}{ }^{24}$ This assignment 

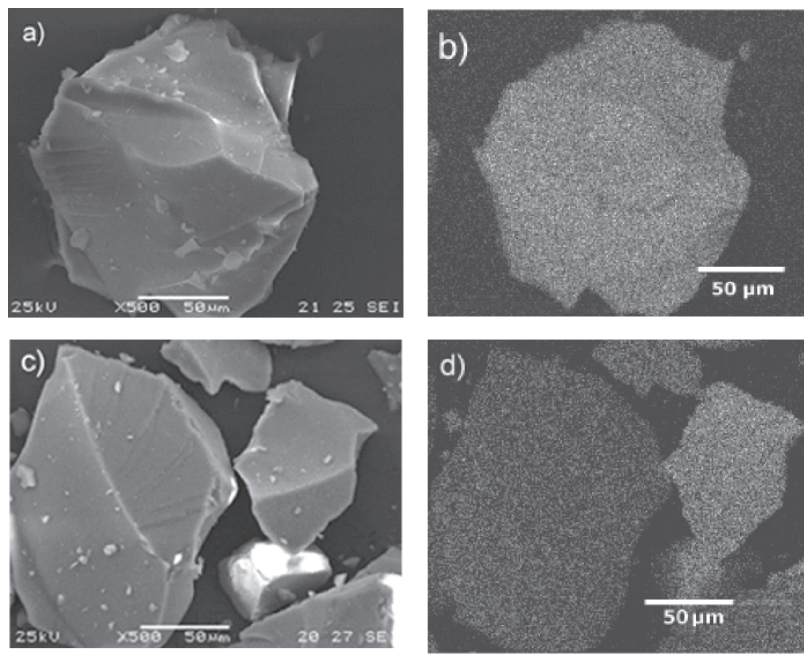

Figure 3. a) Images obtained by MEV, b) the respective cerium mapping by EDS (white points), for SCP3 thermally treated at $473 \mathrm{~K}$ and c) MEV and d) the respective cerium mapping for SCP3 thermally treated at $1273 \mathrm{~K}$.

is also consistent with the presence of dihydrogen phosphate species in various $\mathrm{M}$-phosphates $(\mathrm{M}=\mathrm{Nb}, \mathrm{Ti}$, $\mathrm{Zr}$ and $\mathrm{Al}) .{ }^{17,25-27}$

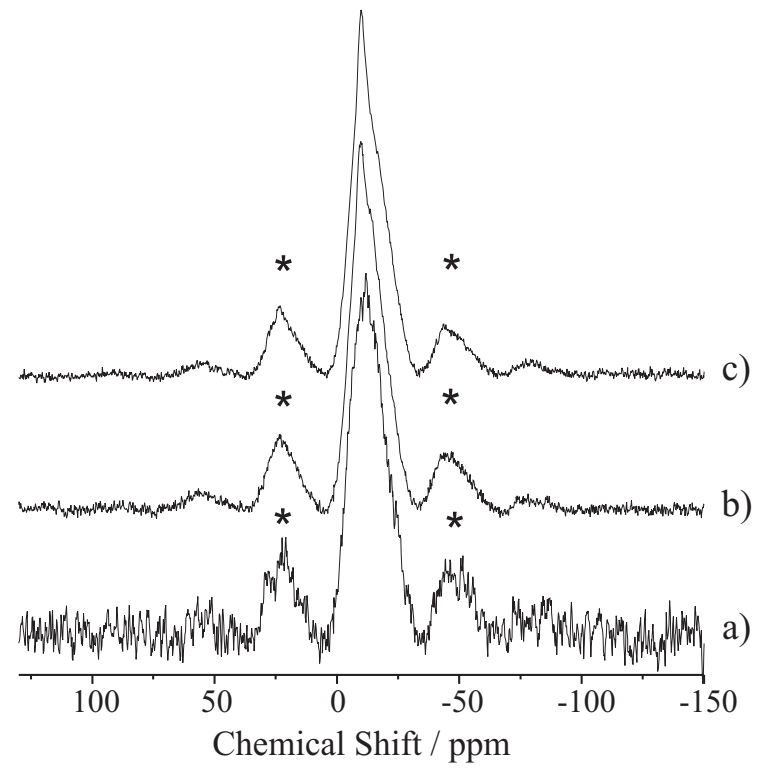

Figure 4. Solid-state ${ }^{31} \mathrm{P}$ MAS/NMR for (a) SCP1, (b) SCP2 and (c) SCP3 thermally treated at $473 \mathrm{~K}$. * side bands.

\section{X-ray Photoelectron Spectroscopy (XPS)}

Table 3 lists the XPS binding energy values (BE) for SCP1, SCP2 and SCP3 thermally treated at $473 \mathrm{~K}$.

The phosphate-adsorbed mixed oxide presented an average binding energy value for the Si $2 p$ peak at $c a$. $103.5 \mathrm{eV}$, with a width at half-maximum of $2.4 \mathrm{eV}$, similar to results from the literature for pure silica. ${ }^{23,28,29}$ All the samples had the XPS spectrum of the O 1s level at 530.6 and $532.4 \mathrm{eV}$, with full width at half-maximum of 2.2 and $2.3 \mathrm{eV}$, attributed to the oxygens present in $\mathrm{SiO}_{2}^{28,29}$ and in $\mathrm{CeO}_{2},{ }^{30}$ respectively.

The XPS of the Ce $3 \mathrm{~d}$ level is complex, since photoemission provokes the re-arrangement of the electrons from the valence level and the resulting final states contain different hybridizations. In Table 3, $v$ " and $v$ " for $\mathrm{CeO}_{2} \mathrm{BE}$ peaks refer to the bonding and antibonding states due to the $\mathrm{Ce} 4 \mathrm{f}$ final state hybridized with the $\mathrm{O} 2 \mathrm{p}$ orbital [the $3 \mathrm{~d}^{9} 4 \mathrm{f}^{1}\left(\mathrm{O}_{2} \mathrm{p}^{5}\right)$ ] electronic configurations and the $\left[3 \mathrm{~d}^{9} 4 \mathrm{f}^{0}\left(\mathrm{O} 2 \mathrm{p}^{6}\right)\right]$ final state ( $\left.v^{\prime \prime \prime}\right)$, respectively. The SCP samples present cerium as $\mathrm{Ce}^{4+} \cdot 30-34$

Phosphorus presented only one photoemission peak, which is assigned to the $\mathrm{P} 2 \mathrm{p}_{3 / 2}$ binding energy at $c a$. $134.0 \mathrm{eV}$ (average value). This binding energy value is assigned to the $\mathrm{H}_{2} \mathrm{PO}_{4}{ }^{-}$species on the surfaces of the three mixed oxides. These values are very close to that observed for phosphate ions adsorbed as $\mathrm{H}_{2} \mathrm{PO}_{4}^{-}$species on the surfaces of $\mathrm{SiO}_{2} / \mathrm{Nb}_{2} \mathrm{O}_{5}{ }^{17}$ and $\mathrm{SiO}_{2} / \mathrm{ZrO}_{2}(134.5$ $\mathrm{eV})^{16}$ sol gel matrices. It is interesting to observe that $\mathrm{P} /$ $\mathrm{Ce}$ atomic ratios obtained were: $\mathrm{SCP} 1=2.8, \mathrm{SCP} 2=$ 2.3 and $\mathrm{SCP} 3=2.7$. These values are not far from $\mathrm{P} / \mathrm{Ce}$ $=2$ ratio expected, if we consider that almost all ceria centers reacted and the species formed is the dihydrogen phosphate species.

The $\mathrm{Ce} / \mathrm{Si}$ atomic ratios calculated for SCP1, SCP2 and SCP3 (Table 3) increased proportionally, taking into account an error of $8 \%$ in the calculation, as the ceria amount increased in these three matrices.

Table 3. $\mathrm{Ce} / \mathrm{Si}$ and $\mathrm{P} / \mathrm{Ce}$ atomic ratios (error of $8 \%$ ) and binding energy (BE) values obtained for SCP samples thermally treated at $473 \mathrm{~K}$

\begin{tabular}{|c|c|c|c|c|c|c|c|c|}
\hline \multirow[t]{3}{*}{ Samples } & \multicolumn{2}{|c|}{ Atomic ratios } & & \multicolumn{5}{|c|}{$\mathrm{BE} / \mathrm{eV}$} \\
\hline & \multirow[t]{2}{*}{$\mathrm{Ce} / \mathrm{Si}$} & \multirow[t]{2}{*}{$\mathrm{P} / \mathrm{Ce}$} & \multirow[t]{2}{*}{ Si $2 p_{3 / 2}$} & \multicolumn{2}{|c|}{$\mathrm{O} 1 \mathrm{~s}$} & \multirow[t]{2}{*}{$\mathrm{P} 2 \mathrm{p}_{3 / 2}$} & \multicolumn{2}{|c|}{ Ce $3 d_{5 / 2}$} \\
\hline & & & & $\mathrm{Si}-\mathrm{O}$ & $\mathrm{Ce}-\mathrm{O}$ & & v"” & v" \\
\hline SCP1 & 0.006 & 2.8 & $103.8(2.5)^{\mathrm{a}}$ & $531.2(2.3)$ & $533.1(2.4)$ & $134.3(2.5)$ & $900.3(3.0)$ & $887.9(3.0)$ \\
\hline SCP2 & 0.008 & 2.3 & $103.5(2.4)$ & $530.5(2.0)$ & $532.7(2.3)$ & $134.0(2.4)$ & $899.6(3.0)$ & $887.6(3.0)$ \\
\hline SCP3 & 0.016 & 2.7 & $103.3(2.4)$ & $530.2(2.4)$ & $532.4(2.5)$ & $133.8(2.5)$ & 899.1(3.0) & $888.3(3.0)$ \\
\hline $\mathrm{CeO}_{2}^{\mathrm{b}}$ & - & - & - & - & $532.0(2.5)$ & - & $898.2(3.0)$ & $888.4(3.0)$ \\
\hline
\end{tabular}

ain parenthesis: full widths at half-maximum; ${ }^{\mathrm{b}} \mathrm{standard} \mathrm{CeO}_{2}$. 


\section{Acidic properties}

An investigation of the acidic properties of the SC and SCP materials was made by using pyridine as a probe molecule. Figure 5 presents the FTIR spectra obtained for the SC3 and SCP3 samples, taken as representatives of the other materials, which did not present any significant difference. The bands at 1599 and $1444 \mathrm{~cm}^{-1}$ are assigned to the $8 \mathrm{a}$ and $19 \mathrm{~b}$ vibrational modes, respectively, of the pyridine molecule bonded to the surface by hydrogen bonds, possibly to the free silanol ( $\equiv \mathrm{SiOH}$ ) groups. ${ }^{35,36}$ We observe in Figures 5(I) and 5(II) that the intensities of these bands decrease on heat treatment under vacuum at $473 \mathrm{~K}$. The band at $1490 \mathrm{~cm}^{-1}$ is assigned to the $19 \mathrm{a}$
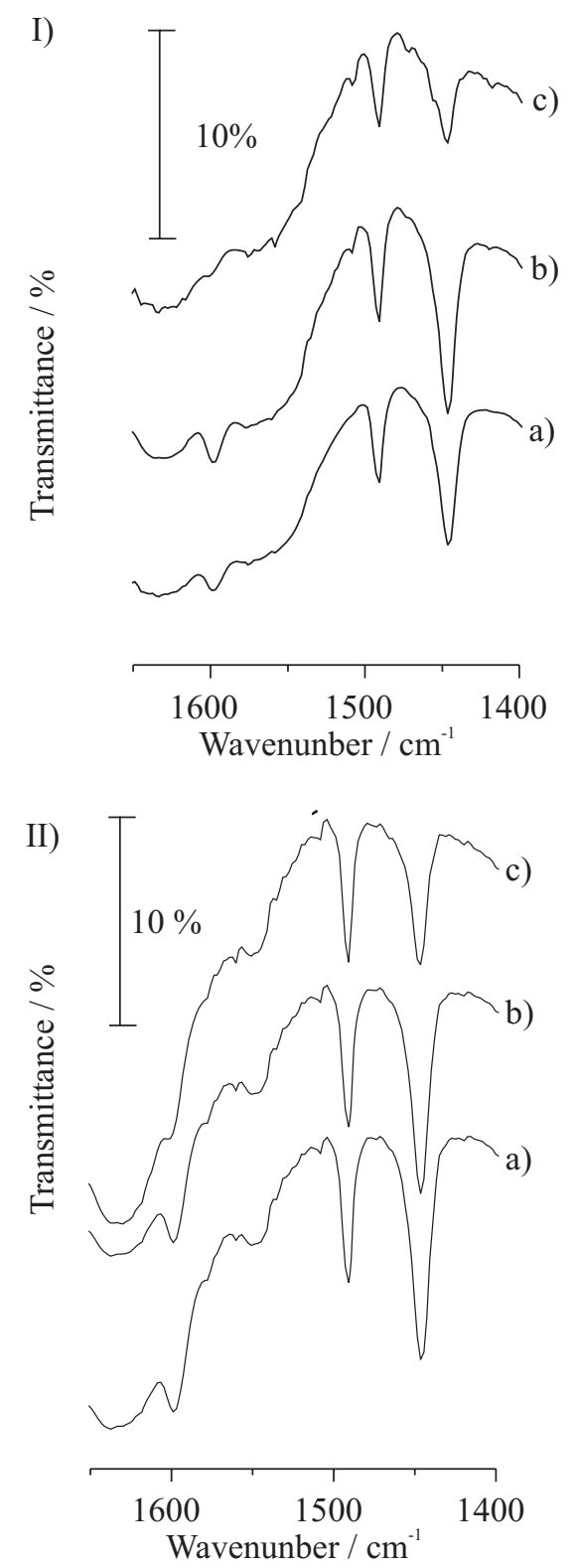

Figure 5. Infrared spectra of pyridine adsorbed on (I) SC3 and (II) SCP3: a) room temperature, b) heated at $373 \mathrm{~K}$ and c) heated at $473 \mathrm{~K}$. vibrational mode and it is always present for all kinds of pyridine adsorption.

The band observed at $1546 \mathrm{~cm}^{-1}$ in Figure 5(II) is assigned to the $19 \mathrm{a}$ vibrational mode of the pyridine molecule adsorbed on Bronsted acid sites. ${ }^{37,38}$ These Brønsted acid sites are due to the $\mathrm{H}_{2} \mathrm{PO}_{4}{ }^{-}$species bonded to the matrix surface by Ce-O-P linkages. The result agrees with the conclusion from X-ray photoelectron spectroscopy, where the spectra of phosphorus presented only one photoemission peak due to the dihydrogen phosphate species on the surface of the mixed oxides. We also observe that they are very stable, since they are present on the surface even after heating the sample at $473 \mathrm{~K}$. In Figure 5(I), for the SC3 sample, the vibrational mode due to pyridine molecules adsorbed on the Brønsted acid sites is not observed. The broadened feature of the band in this region is due to the $\mathrm{OH}$ deformation mode of free silanol $(\equiv \mathrm{SiOH})$ and the attached residual $\mathrm{CeOH}$ groups.

\section{Ammonia gas adsorption}

The infrared spectra of SCP1/NH, $\mathrm{SCP}_{3} / \mathrm{NH}_{3}$ and $\mathrm{SCP} 3 / \mathrm{NH}_{3}$ (solids with adsorbed $\mathrm{NH}_{3}$ ) show a band observed at $\approx 1454 \mathrm{~cm}^{-1}$, as seen in Figure 6 . This vibration mode is assigned to the $\delta \mathrm{NH}_{4}^{+}$deformation mode $\left(\mathrm{F}_{2}\right.$ mode) of the ion having a $\mathrm{T}_{\mathrm{d}}$ symmetry. ${ }^{39}$ The three SCP pure samples do not show this band. Chemical analyses carried out on $\mathrm{SCP} / \mathrm{NH}_{3}$ showed the following amounts of ammonia adsorbed on the surfaces: $\mathrm{SCP} 1 / \mathrm{NH}_{3}=0.37$, $\mathrm{SCP} 2 / \mathrm{NH}_{3}=0.43$ and $\mathrm{SCP} 3 / \mathrm{NH}_{3}=0.51 \mathrm{mmol} \mathrm{g}$.

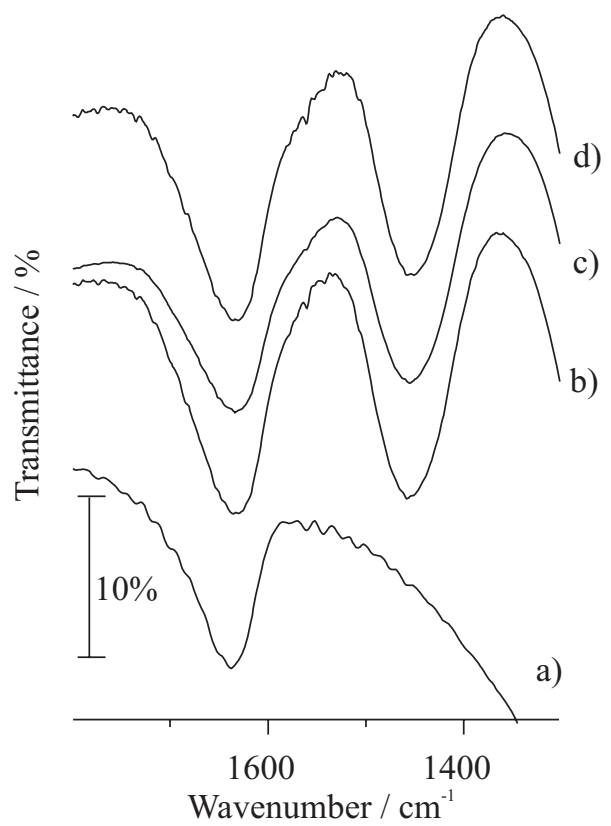

Figure 6. Infrared spectra of a) $\mathrm{SCP} 3$ and with ammonia adsorbed on b) SCP1, c) SCP2 and d) SCP3. 


\section{Conclusions}

$\mathrm{SiO}_{2} / \mathrm{CeO}_{2}$ mixed oxide is obtained as a porous solid in which $\mathrm{CeO}_{2}$ particles interact, through $\mathrm{Si}-\mathrm{O}-\mathrm{Ce}$ bonds, with the $\mathrm{SiO}_{2}$ environment. This assumption is based on the IR absorption band observed at $948 \mathrm{~cm}^{-1}$, assigned to the $v(\mathrm{Si}-\mathrm{O})$ mode of the Si-O-Ce bond. The SEM and EDS images suggest that, within the magnification used, $\mathrm{CeO}_{2}$ particles inside the silica matrix are homogeneously dispersed.

Phosphoric acid reacted with the $\mathrm{CeOH}$ group, resulting in dihydrogen phosphate species attached to the matrix surface, according to the following equation:

$$
\mathrm{SiO}_{2} / \mathrm{CeOH}+\mathrm{H}_{3} \mathrm{PO}_{4} \longrightarrow \mathrm{SiO}_{2} / \mathrm{Ce}-\mathrm{O}-\stackrel{\text { II }}{\stackrel{\mathrm{P}}{\longrightarrow}-\mathrm{OH}}+\mathrm{H}_{2} \mathrm{O}
$$

The average pore diameters of SC and SCP are the same, i.e. $1.7 \mathrm{~nm}$, except in the case of SCP2 where a small increase is observed, i.e. $1.9 \mathrm{~nm}$. This indicates that the formation of cerium phosphate attached to the surface does not block the finest pores of the matrices.

Quantification of $\mathrm{NH}_{3}$ gas adsorbed on the SCP matrices surface, assuming a homogeneous surface, indicated the following surface densities of acid sites on the surface: $\mathrm{SCP} 1=0.78 \times 10^{-10}, \mathrm{SCP} 2=0.90 \times 10^{-10}$ and $\mathrm{SCP} 3=0.95 \times 10^{-10} \mathrm{~mol} \mathrm{~cm}^{-2}$, which correspond to $c a .0 .5$ Brønsted acid sites per $\mathrm{nm}^{2}$.

\section{Acknowledgments}

The research work was partially performed at LME of the National Synchrotron Light Laboratory (LNLS), Brazil. The authors wish to acknowledge Prof. Carol H. Collins (IQ-UNICAMP) for manuscript revision and Rita de C. G. Vinhas for technical assistance. F. L.P. is indebted to CAPES for a doctoral fellowship. M.S.P. F. is indebted to FAPESP for a post-doctoral fellowship (grant 01/012489). Authors Y.G. and R.L. are indebted to FAPESP and CNPq for financial support.

\section{References}

1. Rajesh, K.; Mukundan, P.; Pillai, P. K.; Nair, V. R.; Warrier, K. G. K.; Chem. Mater. 2004, 16, 2700.

2. Ho, L.; Nishiguchi, H.; Nagaoka, K.; Takita, Y.; Mater. Chem. Phys. 2006, 97, 494.

3. Nazaraly, M.; Wallez, G.; Chanéac, C.; Tronc, E.; Ribot, F.; Quarton, M.; Jolivet, J. P.; J. Phys. Chem. Solids 2006, 67, 1075.
4. Tang, C.; Bando, Y.; Goldberg, C.; Ma, R.; Angew. Chem., Int. Ed. 2005, 44, 576.

5. Hirai, H.; Masui, T.; Imanaka N.; Adachi, G.; J. Alloys Compd. 2004, 374, 84.

6. Imanaka, N.; Masui, T.; Hirai, H.; Adachi, G.; Chem. Mater. 2003, 15, 2289.

7. Riwotzki, K.; Meyssamy, H.; Kornowski, A.; Haase, M.; J. Alloys Compd. 2000, 104, 2824.

8. Nilchi, A.; Khanchi, A.; Maragheh, M. G.; Talanta 2002, 56, 383.

9. Rocha, G. M. S. R. O.; Johnstone, R. A. W.; Neves, M. G. P. M. S.; J. Mol. Catal. A: Chem. 2002, 187, 95.

10. Varshney, K. G.; Tayal, N.; Colloids Surf., A 2000, 162, 49.

11. Varshney, K. G.; Tayal, N.; Gupta, P.; Agrawal, A.; Drabik, M.; Indian J. Chem., A 2004, 43, 2586.

12. Ribeiro, E. S.; Rosatto, S. S.; Gushikem, Y.; Kubota, L. T.; J. Solid State Electrochem. 2003, 7, 665.

13. Cardoso, W.S.; Francisco, M. S. P.; Lucho, A. M. S.; Gushikem, Y.; Solid State Ionics 2004, 167, 165.

14. Francisco, M. S. P.; Landers, R.; Gushikem, Y.; J. Solid State Chem. 2004, 177, 2431.

15. Gonçalves, J. E.; Gushikem Y.; de Castro, S. C.; J. Non-Cryst. Solids 1999, 260, 125.

16. Alfaya, A.A.S.; Gushikem, Y.; de Castro, S.C.; Microporous Mesoporous Mater. 2000, 39, 57.

17. Francisco, M.S.P.; Cardoso, W.; Gushikem Y.; Kholin, Y.V.; Langmuir 2004, 20, 8707.

18. Craciun, R.; Solid State Ionics 1998, 110, 83.

19. Alfaya, A.A.S.; Gushikem, Y.; de Castro, S.C.; Chem. Mater. 1998, 10, 909.

20. Kawano, Y.; Denofre S.; Gushikem, Y.; Vib. Spectrosc. 1994, 7, 293.

21. Nigishi, N.; Fujii T.; Anpo, M.; Langmuir 1993, 9, 3320.

22. Huter, R.; Dutoit, D.C.M.; Mallat, T.; Schneider M.; Baiker, A.; J. Chem. Soc. Chem. Commun. 1995, 2, 163.

23. Scofield, J.H.; J. Electron Spectrosc. 1976, 8, 129.

24. Hayashi, H.; Torii, K.; Nakata, S.; J. Mater. Chem. 1997, 3, 557.

25. Chen, C.; Yang, Y. L.; Huang, K. L.; Sun, Z.H.; Wang, W.; Yi, Z.; Lin, Y. L.; Pang, W.Q.; Polyhedron 2004, 23, 3033.

26. Takahashi, H.; Oi, T.; Hosoe, M.; J. Mater. Chem. 2002, 12, 2513.

27. Nakayama, H.; Eguchi, T.; Nakamura, N.; Yamaguchi, S.; Danjyo, M.; Tasuhako, M.; J. Mater. Chem. 1997, 7, 1063.

28. Pârvulescu, V.; Pârvulescu, V. I.; Grange, P.; Catal. Today 2000, 57, 193.

29. Francisco, M. S. P.; Landers, R.; Gushikem, Y.; J. Solid State Chem. 2004, 177, 2432.

30. Francisco, M. S. P.; Mastelaro, V. R.; Nascente, P. A. P.; Florentino, A.O.; J. Phys. Chem. B 2001, 105, 10515.

31. Larsson, P. O.; Andersson, A.; J. Catal. 1998, 179, 72. 
32. Shyu, J. Z.; Weber, W. H.; Gandhi, H. S.; J. Phys. Chem. 1988, $92,17$.

33. Bak, K.; Hilaire, L.; Appl. Surf. Sci. 1993, 70-71, 191.

34. Ernst, B.; Hilaire, L.; Kiennemann, A.; Catal. Today 1999, 50, 413.

35. Parry, E.; J. Catal. 1963, 2, 371.

36. Benvenutti, E. V.; Gushikem, Y.; Davanzo, C. U.; de Castro, S. C.; Torriani, I. L.; J. Chem. Soc. Faraday Trans. 1992, 88, 3193.

37. Morterra, C.; Cerrato, G.; Langmuir 1990, 6, 1810.
38. Benvenutti, E. V.; Gushikem Y.; Davanzo, C.U.; Appl. Spectrosc. 1992, 46, 1474.

39. Clearfield, A; Stynes, J.A.; J. Inorg Nucl. Chem. 1964, 26, 117.

Received: September 26, 2006

Web Release Date: August 8, 2007

FAPESP helped in meeting the publication costs of this article. 